\title{
Fate of straw- and root-derived carbon in a Swedish agricultural soil
}

\author{
Abdul Ghafoor $^{1}$ (I) $\cdot$ Christopher Poeplau $^{2} \cdot$ Thomas Kätterer $^{1}$
}

Received: 5 September 2016 / Revised: 14 November 2016 / Accepted: 25 November 2016 / Published online: 7 January 2017

(C) The Author(s) 2017. This article is published with open access at Springerlink.com

\begin{abstract}
To maximise carbon (C) storage in soils, understanding the fate of $\mathrm{C}$ originating from aboveground and belowground residues and their interaction with fertiliser under field conditions is critically important. The use of ${ }^{13} \mathrm{C}$ natural abundance provides unique opportunities to separate both $\mathrm{C}$ sources. We investigated the effect of 16 years of $\mathrm{C} 3$ straw and $\mathrm{C} 4$ root input, with and without nitrogen $(\mathrm{N})$ addition, on SOC stocks and $\mathrm{C}$ distribution in soil fractions in the long-term frame trial at Ultuna, Sweden. The straw C input was fixed at $1.77 \mathrm{Mg} \mathrm{ha}^{-1}$ year $^{-1}$, while the root input depended on maize plant growth, enabling studies on how $\mathrm{N}$ fertilisation affected (i) stabilisation of residues and (ii) plant $\mathrm{C}$ allocation to belowground organs. Four treatments were investigated: only maize roots (Control), maize roots with $\mathrm{N}$ (Control + $\mathrm{N}$ ), maize roots and straw (Straw) and maize roots, straw and $\mathrm{N}($ Straw $+\mathrm{N})$. After 16 years, $5.6-8.9 \%$ of the total SOC stock in the $0-20 \mathrm{~cm}$ soil layer was maize-derived. In all four treatments, the relatively labile SOC fractions decreased, while the proportion of more refractory fractions increased. Based on allometric calculation of root inputs, retention of maize roots was 38, 26, 36 and $18 \%$ in the Control, Control $+\mathrm{N}$, Straw and Straw $+\mathrm{N}$ treatments, respectively. The estimated retention coefficient of C3 straw in the Straw + $\mathrm{N}$ treatment was higher than that in the Straw-N treatment. We
\end{abstract}

Abdul Ghafoor

abdul.ghafoor@slu.se

1 Department of Ecology, Swedish University of Agricultural Sciences (SLU), Box 7044, 75007 Uppsala, Sweden

2 Thuenen Institute of Climate-Smart Agriculture, Bundesallee 50, 38116 Braunschweig, Germany interpreted these results thus (1) roots were better stabilised in the soil than straw; (2) $\mathrm{N}$ fertilisation caused a shift in root to shoot ratio, with relatively more roots being present in $\mathrm{N}$ deficient soil; and (3) $\mathrm{N}$ fertilisation caused greater stabilisation of residues, presumably due to increased microbial C use efficiency.

Keywords Carbon sequestration · Fractionation - Carbon modelling $\cdot$ Stable isotopes $\cdot \mathrm{C}$ input

\section{Introduction}

Soil organic matter (SOM) serves many ecosystem functions from being reservoir for nutrients to act as agent to increase biological activity, provides soil aggregation, retains moisture and improves soil structure and tilth for reducing soil erosion. Moreover, SOM comprises a significant part of the global terrestrial $\mathrm{C}$ pool. The world's soils store at least three times as much $\mathrm{C}$ as is found in either the atmosphere or living plants (Lal 2004). A small change in the SOC pool has a critical influence on atmospheric $\mathrm{CO}_{2}$ concentration (Poeplau et al. 2011; von Lützow et al. 2006). Kell (2012) postulated that an overall increase in soil C of $10 \%$ would decrease atmospheric $\mathrm{C}$ by at least $20 \%$. Thus, given the growing interest in increasing SOC stocks in soils world-wide to mitigate climate change and improve soil quality, better understanding of soil organic $\mathrm{C}$ (SOC) stabilisation and its dynamics in soil in response to various management practises is indispensable ( $\mathrm{Lal} 2004)$.

Conceptually, SOC is often partitioned into different pools/ fractions with distinct physico-chemical properties, different degrees of stabilisation and turnover times ranging from years to millennia (Bol et al. 2009; von Lützow et al. 2007). A variety of biochemical, physical and chemical processes protect organic $\mathrm{C}$ from decomposition in soils, and knowledge of 
the resulting persistence of SOC pools/fractions in soil is vital in understanding their contribution to the global $\mathrm{C}$ cycle. Stabilisation of SOC in soil depends on numerous factors such as soil type, climate, substrate quality, input pathway and nutrient regime (Kätterer et al. 2011; Kirkby et al. 2013). In a mechanistic perspective, four major mechanisms may explain the stability of SOM in soil: (i) spatial inaccessibility of SOM to decomposers due to aggregation, (ii) recalcitrance due to the chemical structure, (iii) stabilisation of SOM by interaction with mineral surfaces and (iv) energetical limitation microbes to decompose organic matter (Mueller et al. 2014; von Lützow et al. 2006; Fontaine et al. 2007). The distribution of organic matter between soil size fractions is affected differently when soil organic matter levels change due to cultivation, straw incorporation, addition of mineral fertiliser or animal manure (Christensen and Sorensen 1985; Christensen 1987; Gregorich et al. 1995).

Using a detailed balancing approach, Kätterer et al. (2011) showed that root-derived $\mathrm{C}$ was preferentially retained in soil and contributed 2.3 -fold more to the $\mathrm{C}$ pool than aboveground residues. Potential reasons for this, as elegantly summarised by Rasse et al. (2005), are as follows: (i) roots are relatively more recalcitrant than shoots; (ii) the physico-chemical protection of root $\mathrm{C}$ by aggregates and mineral surfaces is higher than for shoot $\mathrm{C}$; and (iii) the decomposability of roots is lower due to accumulation of metal ions. Separating shootand root-derived $\mathrm{C}$ inputs in dynamic modelling has been shown to increase model accuracy (Poeplau et al. 2015). However, at the same time, root biomass is seldom measured and has to be estimated using allometric functions involving yield-based allocation coefficients (Bolinder et al. 2007), which are usually based on mean values from a limited number of studies. Shifts in plant allocation to aboveground and belowground organs due to, e.g. alterations in management are not accounted for in those approaches, but are also not sufficiently studied. There is thus considerable uncertainty regarding root-derived $\mathrm{C}$ inputs and their fate in the soil in relation to shoot-derived C inputs. Separation of these two $\mathrm{C}$ sources may be possible by the use of biomarkers (MendezMillan et al. 2010), but more research is needed in this field. The Ultuna long-term soil organic matter field experiment in Sweden, which was established 60 years ago, offers a unique opportunity for separate studies of root- and shoot-derived C turnover in the soil. Since the beginning of the experiment, aboveground residues of any crops grown are completely removed, so that the only direct crop-derived $\mathrm{C}$ input is rootderived. In 2000, the crop rotation was shifted to maize monoculture, thereby introducing a $\mathrm{C} 4$ plant to a previously pure ' $\mathrm{C} 3$ soil'. The experiment is intended to study the effect of different mineral $\mathrm{N}$ fertilisers and organic amendments on soil organic matter. Among those amendments, C3-wheat straw is added to the soil. This offers the opportunity to study the dynamics of straw- and root-derived $\mathrm{C}$ separately by measuring the natural abundance of the stable isotope ${ }^{13} \mathrm{C}$ and using the data for tracing and quantifying sources, sinks and flux rates within the biogeochemical $\mathrm{C}$ cycle (Boutton 1996). This separation of $C$ sources is due to higher discrimination of ${ }^{13} \mathrm{C}$ in $\mathrm{C} 3$ photosynthesis (Calvin cycle) than in $\mathrm{C} 4$ photosynthesis (Hatch-Slack pathway) (Farquhar et al. 1989). The $\delta^{13} \mathrm{C}$ values from plants with $\mathrm{C} 3$ photosynthesis typically range from -40 to $-23 \%$, while those in plants with $\mathrm{C} 4$ photosynthesis range from -19 to $-9 \%$ (Boutton et al. 1998). After a C3-C4 vegetation change, the relative contribution of new and old SOC can be estimated based on the mass balance of $\mathrm{C}$ isotope content and the isotopic signature can thus be used to follow the dynamics of SOC in situ.

Soil nutrient regime influences SOC dynamics. Nitrogen fertilisation is known to increase net primary production and thus C inputs to the soil (Christopher and Lal 2007; Kätterer et al. 2012). However, $\mathrm{N}$ availability also influences plant $\mathrm{C}$ allocation to belowground organs, with more investment in belowground organs under $\mathrm{N}$ deficiency (Welbank et al. 1973). Furthermore, $\mathrm{N}$ fertilisation is reported to increase soil $\mathrm{C}$ retention due to increased microbial use efficiency (Kirkby et al. 2013; Kirkby et al. 2014). Under N deficiency, decomposers have been shown to use fresh organic matter as an energy source for the break-up of more recalcitrant, but nutrient rich organic matter (Murphy et al. 2015; Poeplau et al. 2016a). However, the relevance of each of these mechanisms for SOM dynamics is not sufficiently understood (Poeplau et al. 2016a). In the Ultuna experiment, a factorial combination of straw and $\mathrm{N}$ fertilisation is applied. The prevailing effect of $\mathrm{N}$ fertilisation on SOM dynamics can thus be identified when using the approach with ${ }^{13} \mathrm{C}$ natural abundance described above.

The given experimental set up thus enabled us to formulate three different hypotheses at the same time, which are all related to aspects of soil organic matter dynamics that are currently debated. From such a systematic approach, the relative importance of specific mechanisms might be inferred. We hypothesised that (i) root-derived carbon was generally better stabilised in the soil than straw-derived carbon, (ii) nitrogen fertilisation did relatively reduce carbon allocation to belowground organs and (iii) nitrogen fertilisation did increase the stabilisation of fresh root- or straw-derived carbon.

\section{Material and methods}

\section{Study site}

The Ultuna long-term agricultural field experiment is located in Uppsala, Sweden $\left(59.82^{\circ} \mathrm{N}, 17.65^{\circ} \mathrm{E}\right)$ and was initiated in 1956 to investigate the effect of various organic amendments with or without addition of mineral $\mathrm{N}$ fertiliser. The topsoil ( 0 $20 \mathrm{~cm})$ is a clay loam with $36.5 \%$ clay, $41 \%$ silt $(0.002$ 
$0.06 \mathrm{~mm})$ and $22.5 \%$ sand $(0.06-2.0 \mathrm{~mm})$ and has been classified as a Typic Eutrochrept (USDA soil taxonomy) or Eutric Cambisol (FAO classification) (Kirchmann et al. 1996). At the start of the experiment, soil $\mathrm{pH}$ was 6.5. The experimental design consisted of 15 treatments with four replicate plots in a randomised block design, giving a total of 60 plots. The plots $(2 \mathrm{~m} \times 2 \mathrm{~m})$ are separated by $40 \mathrm{~cm}$ high steel frames inserted into the ground to a depth of about $30 \mathrm{~cm}$. Inorganic $\mathrm{N}$ fertiliser as calcium nitrate is added annually during spring at a rate of $80 \mathrm{~kg} \mathrm{~N} \mathrm{ha}^{-1}$ year $^{-1}$ in the $\mathrm{N}$-fertilised treatments. Straw (stems and leaves of winter wheat) was applied biannually in the autumn at a rate of $1.77 \mathrm{Mg} \mathrm{C} \mathrm{ha}^{-1}$ year $^{-1}$ (Kätterer et al. 2011). Straw properties are described in detail by Peltre et al. (2012). Although microbial biomass is a small part of the total soil organic carbon (SOC) pool, it plays a major role in its turnover. The data on microbial biomass has recently been published by Börjesson et al. (2016). The experiment also includes a control treatment that receives neither $\mathrm{N}$ fertiliser nor organic amendments. All plots receive a basic annual fertiliser application of $20 \mathrm{~kg}$ phosphorus (P) ha ${ }^{-1}$ and $38 \mathrm{~kg}$ potassium (K) ha ${ }^{-1}$. From 1956 to 1999 , annual crops with a C3 photosynthetic pathway, such as oats, spring barley, beet, rape, turnip and mustard, were cultivated. Since the start of the experiment, tillage of plots has been managed manually (Kätterer et al. 2011; Kirchmann et al. 1996). Tillage was normal and homogenous across all treatments. All plots are 'tilled' with a spade to $20 \mathrm{~cm}$ depth every autumn. After 1999 , silage maize has been grown continuously. All aboveground plant material is removed every year at harvest. A sample archive of topsoil, plant materials and amendments has been maintained since 1956.

\section{Soil sampling and analysis}

In early autumn 2015, soil was sampled at 0-20 cm depth in each of the four replicates of the following four treatments: unfertilised (Control), calcium nitrate (Control $+\mathrm{N})$, straw (Straw), and straw plus calcium nitrate $(\mathrm{Straw}+\mathrm{N})$. In the following, Control and Straw are combined and summarised as $-\mathrm{N}$ treatments and the Control $+\mathrm{N}$ and Straw $+N$ are summarised as $+N$ treatments. Since 2000 , the Control and Control $+\mathrm{N}$ treatments have received only belowground $\mathrm{C}$ inputs from maize, whereas $\mathrm{C}$ inputs in Straw and Straw $+\mathrm{N}$ derive from both $\mathrm{C} 3$ and $\mathrm{C} 4$ plants (C3 $\mathrm{C}$ from grain straw and $\mathrm{C} 4 \mathrm{C}$ from maize roots and rhizodeposits). From each plot, five auger samples were taken and bulked together to provide one composite sample. The samples were air-dried prior to further analysis. In addition, soil samples from 1999 taken in the same plots as those sampled in 2015 were obtained from the historical archive of the experiment. Thus, we had soil samples from 2 years, four treatments and four replicates, which added up to 32 samples in total.

\section{SOC fractionation}

Numerous fractionation schemes have been developed to separate and analyse SOM fractions (von Lützow et al. 2007). One increasingly widespread scheme (proposed by Zimmermann et al. 2007) separates SOC into five operationally-defined pools/fractions analogous to the pools considered in dynamic SOC models such as the RothC model (Coleman and Jenkinson 1999). In this study, a 30-g portion of dry soil from each field plot sampled in 1999 and 2015 was subjected to the fractionation procedure proposed by Zimmermann et al. (2007) to obtain the following five fractions: particulate organic matter (POM), dissolved organic C (DOC) (both considered to be active $\mathrm{C}$ pools), SOC attached to sand grains and in stable aggregates (SA), SOC attached to silt and clay particles without being chemically resistant (SC-rSOC) (both considered to be slow cycling) and a chemically resistant fraction (rSOC) (considered to be passive). An overview of the fractionation scheme is provided in Fig. 1. In brief, the SC fraction was separated from the SA fraction by wet sieving after ultrasonic dispersion, POM was separated by density fractionation using sodium polytungstate solution $\left(1.8 \mathrm{~g} \mathrm{~cm}^{-3}\right)$, DOC was measured in the water used for wet sieving and the rSOC fraction was obtained after 3 days of oxidation with $\mathrm{NaOCl}$. Thereby, an aliquot of $1 \mathrm{~g}$ of the silt and clay (SC) fraction was used for oxidation and the remaining SOC after oxidation was multiplied with the total fraction mass of the SC fraction. The size of the SC-rSOC fraction was thus calculated by difference.

\section{Chemical analysis}

Soil $\mathrm{C}$ and $\mathrm{N}$ were analysed using an elemental analyser (LECO CN-2000, St. Joseph, Michigan, USA) and the ${ }^{13} \mathrm{C}$ abundance in SOC was determined with a different type of elemental analyser (model EuroEA3024; Eurovector, Milan, Italy) coupled online to a continuous flow Isoprime isotope-

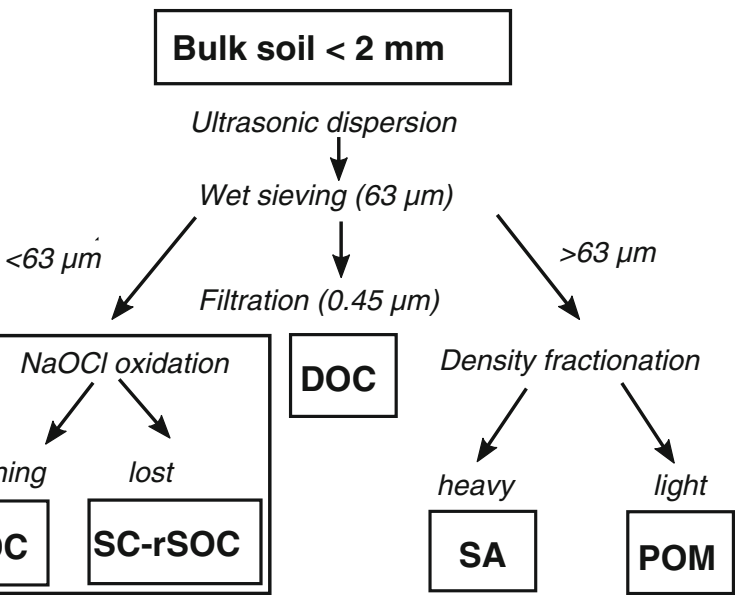

Fig. 1 Overview of the applied fractionation scheme as introduced by Zimmermann et al. (2007) 
ratio mass spectrometer (GV Instruments; Manchester, UK) at Lund University. The resulting $\delta^{13} \mathrm{C}$ values were expressed in parts per thousand (\%o) relative to the international standard of Vienna Pee Dee Belemnite (V-PDB):

$\delta^{13} \mathrm{C}=1000 \times\left(\frac{R_{\text {sample }}-R_{\text {standard }}}{R_{\text {standard }}}\right) \%$ o

where $R_{\text {sample }}$ is the isotope ratio of ${ }^{13} \mathrm{C}$ to ${ }^{12} \mathrm{C}$ of the sample, and $R_{\text {standard }}$ is the ${ }^{13} \mathrm{C} /{ }^{12} \mathrm{C}$ ratio of the international Pee Dee formation belemnite Cate standard (PDB) which is equal to 0.0112372 . The average recovery of total carbon and ${ }^{13} \mathrm{C}$ in all fractions (POM, DOC, SA, SC) combined was 89 and $88 \%$, respectively. We assumed that each fraction lost a similar amount of carbon during fractionation and corrected those losses accordingly. The DOC concentration was determined with a liquid analyser (DIMATOC 2000; Dimatec, Essen, Germany). For the analysis in the mass spectrometer, the DOC fraction was freeze dried. An appropriate amount of each sample (depending on its $\mathrm{C}$ concentration) was enclosed in tin ( $\mathrm{Sn})$ capsules for isotope analysis.

\section{Estimation of C3- and C4-derived SOC}

The fraction of maize-derived total SOC $\left(f_{\mathrm{M}}\right)$ was estimated by isotope mass balance as described by Balesdent et al. (1987):

$f_{\mathrm{M}}=\frac{\delta^{13} C_{\text {soil,2015 }}-\delta^{13} C_{\text {soil }, 1999}}{\delta^{13} C_{\text {maize }}-\delta^{13} C_{\text {soil, } 1999}}$

where the $\delta^{13} \mathrm{C}$ values represent those measured in the soils in 1999 and 2015. The maize signature, $-12.3 \%$ (SE <0.1), was taken from Menichetti et al. (2013), who found low variation in the different plant parts in maize from the Ultuna experiment. The mass of SOC deriving from maize was then calculated by multiplying $f_{\mathrm{M}}$ by the SOC mass to $0-20 \mathrm{~cm}$ depth. The SOC stocks (Table 2) were calculated from SOC concentrations in the soil samples from 1999 and 2014 using bulk density values that were measured in 2009 in the different treatments (Kätterer et al. 2011).

To estimate the mass change in $\mathrm{C} 3 \mathrm{C}$ stocks due to straw addition $\left(\triangle \mathrm{SOC}(\mathrm{Straw})_{\mathrm{c} 3}\right)$ during the time between 1999 and 2015, the total SOC stock difference between straw-amended and non-amended treatments in 1999 was first subtracted from this difference in 2015:

$$
\begin{aligned}
& \Delta \mathrm{SOC}(\text { Straw })_{\text {Total }} \\
& \quad=\left(\mathrm{SOC}_{\text {straw }}-\mathrm{SOC}_{\text {no straw }}\right)_{2015}-\left(\mathrm{SOC}_{\text {straw }}-\mathrm{SOC}_{\text {no straw }}\right)_{1999}
\end{aligned}
$$

To calculate the contribution of $\mathrm{C} 3$ straw to this difference, the difference in $\mathrm{C} 4$ SOC stock between the straw-amended and non-straw-amended treatments was subtracted from $\triangle \mathrm{SOC}(\mathrm{Straw})_{\mathrm{Total}}:$ :

$$
\begin{aligned}
& \Delta \operatorname{SOC}(\text { Straw })_{\mathrm{C} 3} \\
& \quad=\Delta \operatorname{SOC}(\text { Straw })_{\text {Total }}-\Delta \mathrm{SOC}(\text { Straw })_{\mathrm{C} 4}
\end{aligned}
$$

This was done for both $+\mathrm{N}$ treatments, to investigate the effect of $\mathrm{N}$ on SOC dynamics in straw and roots.

Finally, separate retention coefficients $(\mathrm{R})$ were derived for straw and maize input, to describe the efficiency of $\mathrm{C}$ retention for each of the two input types:

$R_{i}=\frac{\Delta \mathrm{SOC}_{i}}{I_{i}}$

where $I i$ is the total cumulative C input between 1999 and 2014 (C3 straw or $\mathrm{C} 4$ roots). For the straw, the cumulative input was rather exactly known $\left(28 \mathrm{Mg} \mathrm{C} \mathrm{ha}^{-1}\right)$, while the root-derived $\mathrm{C}$ input had to be estimated using the yield-based allocation coefficients described in Bolinder et al. (2007), who estimated the proportion of net primary production to be allocated belowground for silage maize is $22.8 \%$. Since root allocation according to Bolinder et al. (2007) accounts for root inputs to $40 \mathrm{~cm}$ depth, root inputs to $20 \mathrm{~cm}$ depth were estimated by methodology proposed by Kätterer et al. (2011) using MichaelisMenten-type function and accounted for $71 \%$ of the total root biomass. However, this method of $\mathrm{C}$ estimation is independent of nutrient effects on $\mathrm{C}$ allocation, which have been observed before (Welbank et al. 1973). Observed differences in C4 retention between the $\mathrm{N}$-fertilised and unfertilised treatments might thus indicate a shift in root to shoot ratio due to $\mathrm{N}$ availability (Table 1, E and F). Table 1 presents potential results for the treatment combinations investigated and lists their most likely explanations, as derived from the potentially involved mechanisms listed in the introduction.

\section{Statistical analyses}

Data analysis was performed within the $\mathrm{R}$ statistical environment (R Development Core Team, 2010). Analysis of variance was conducted for each fraction. Post-hoc (Tukey's HSD) tests were applied for assessing differences between treatments for which the $\mathrm{C}$ distribution showed significant treatment effects $(F$-test, $p<0.05)$.

\section{Results and discussions}

\section{Cumulative $\mathrm{C}$ input}

Cumulative C inputs for the period 1999-2015 were calculated from aboveground biomass yield (Table 2). When using the allocation coefficients for yield-based estimates of $\mathrm{C}$ inputs, 
Table 1 Potential results and their possible interpretations

\begin{tabular}{lll}
\hline Result & Retention coefficient $(\mathrm{R})$ & Interpretation \\
\hline $\mathrm{A}$ & Equal for roots and shoots & No difference in $\mathrm{C}$ sequestration efficiency \\
$\mathrm{B}$ & Higher for roots than for shoots & Roots are better stabilised than shoots \\
$\mathrm{C}$ & Higher for roots and shoots in the $+\mathrm{N}$ treatments & $\mathrm{N}$ increases microbial C use efficiency \\
$\mathrm{D}$ & Lower for roots and shoots in the $+\mathrm{N}$ treatments & $\mathrm{N}$ increases turnover of $\mathrm{C}$ \\
$\mathrm{E}$ & Different for roots, but equal for shoots in the $+\mathrm{N}$ treatments & $\mathrm{N}$ fertilisation alters root/shoot ratio \\
$\mathrm{F}$ & Lower for roots but higher for shoots in the $-\mathrm{N}$ treatments & $\mathrm{N}$ fertilisation alters root/shoot ratio and \\
& & increases microbial C use efficiency. \\
\hline
\end{tabular}

the control treatment yielded the lowest $\mathrm{C}$ inputs from roots and rhizodeposition. Biomass production and corresponding $\mathrm{C}$ inputs from maize increased in response to $\mathrm{N}$ fertilisation and straw addition. $\mathrm{C}$ input through maize residues during the period 1999-2015 was only 5.1 $\mathrm{Mg} \mathrm{ha}^{-1}$ in the Control, but ranged from 7.1 to $14.1 \mathrm{Mg} \mathrm{C} \mathrm{ha}^{-1}$ in the treatments amended with N, straw or both (Table 2).

Cultivation of grain maize can provide an annual $\mathrm{C}$ input of 5-15 $\mathrm{Mg} \mathrm{ha}^{-1}$ (Clapp et al. 2000; Liang et al. 1998). However, the $\mathrm{C}$ input from forage maize is usually much lower, since most of aboveground biomass is harvested. Our $\mathrm{C}$ input estimates (0.31-0.88 $\mathrm{Mg} \mathrm{C} \mathrm{ha}^{-1}$ year $^{-1}$, Table 2) correspond to those presented by others for forage maize. Kristiansen et al. (2005) estimated that roots and stubble together left annually $0.25-0.48 \mathrm{Mg} \mathrm{C} \mathrm{ha}^{-1}$ during a period of 14 years, while Wang et al. (2015) estimated average annual $\mathrm{C}$ input for the periods of 1990-2002 and 2003-2009 through maize residues to be 0.27-0.39 $\mathrm{MgC} \mathrm{ha}^{-1}$ and 0.59-1.52 $\mathrm{MgCha}^{-1}$ under unfertilised and fertilised mono-cropping, respectively.

\section{Total SOC stock changes and the contributions of $\mathrm{C3}$ and $\mathrm{C} 4 \mathrm{C}$}

The stocks of SOC for each treatment in the 2 years compared here are presented in Table 2 and Fig. 1. During the 16-year period considered, the soil $\mathrm{C}$ balance was negative in all treatments except Straw $+\mathrm{N}$, which gained a non-significant amount of $\mathrm{C}\left(0.2 \mathrm{Mg} \mathrm{ha}^{-1}\right)$ (Table 2). After 60 years, this treatment may be close to steady state. Both $\mathrm{N}$ fertilisation and straw addition increased the SOC stock in the $0-20 \mathrm{~cm}$ layer, to a great extent during the whole experimental period but also slightly during the 16-year period considered here. The SOC stocks in 2015 were 5.0 and $5.7 \mathrm{Mg} \mathrm{C}^{-1}$ higher in $\mathrm{N}$-fertilised treatments than their unfertilised counterparts without and with straw addition, respectively. The corresponding change in SOC during the 16-year period was 1.9 and $2.6 \mathrm{Mg} \mathrm{ha}^{-1}$, respectively. The long-term (from 1956 to 2015) increase in SOC due to straw addition was 11.4 and 12.1 $\mathrm{Mg} \mathrm{ha}^{-1}$ in $-\mathrm{N}$ and $+\mathrm{N}$ treatments, respectively, and the corresponding short-term effect (recent 16 years) was 1.6 and $2.3 \mathrm{Mg} \mathrm{C} \mathrm{ha}^{-1}$, respectively (Fig. 1, Eq. 3). The isotopic analysis revealed that between 5.6 and $8.9 \%$ of SOC in 2015 was derived from maize (Table 2). Very similar values $(7,8,7$ and $5 \%$ for Control, Control $+\mathrm{N}$, Straw and Straw $+\mathrm{N}$ treatments, respectively) were quantified in the same field experiment in 2009, 10 years after the introduction of maize (Menichetti et al. 2013). In contrast to what we expected, the C4-derived $\mathrm{C}$ pool had not significantly increased during the intervening 6 years. Nevertheless, our results are in line with those reported by others. Kristiansen et al. (2005) found that the proportion of soil total $\mathrm{C}$ originating from maize roots and stubble was $7-18 \%$ (corresponding to $3.5-6.9 \mathrm{Mg} \mathrm{C}^{-1}$ ) after 14 years of continuous cropping. However, our findings are in contrast to the $22-42 \%$ maize-derived $\mathrm{C}$ in the whole soil reported in other studies (Balesdent et al. 1988; Gregorich et al. 1997; Haile-Mariam et al. 2008). This discrepancy was partly due to a shorter period of continuous maize cultivation in our case (16 years) compared with other studies (e.g.

Table 2 Soil organic C (SOC) stocks $(0-20 \mathrm{~cm})$ and specific retention coefficient of maize residues and $\mathrm{C} 3$ straw of the selected treatments in the Ultuna long-term experiment. Errors given are standard deviations

\begin{tabular}{|c|c|c|c|c|c|c|c|c|}
\hline \multirow[t]{2}{*}{ Treatment } & \multicolumn{2}{|c|}{$\begin{array}{l}\text { SOC stocks } \\
(\mathrm{Mg} \mathrm{C} \text { ha }-1)\end{array}$} & \multirow{2}{*}{$\begin{array}{l}\text { Yield } \\
\left(\mathrm{Mg} \mathrm{DM} \mathrm{ha}^{-1}\right) \\
\begin{array}{l}2000 \text { through } \\
2015\end{array}\end{array}$} & \multirow[t]{2}{*}{$\begin{array}{l}\text { Estimated C4 input } \\
\left(\mathrm{Mg} \mathrm{C} \text { ha- }^{1} \text { year }^{-1}\right)\end{array}$} & \multirow[t]{2}{*}{$\begin{array}{l}\text { C3 input } \\
\text { (Mg C ha-1 year-1) }\end{array}$} & \multirow{2}{*}{$\begin{array}{l}\begin{array}{l}\text { Proportion } \\
\text { of C4 C (\%) }\end{array} \\
2015\end{array}$} & \multirow[t]{2}{*}{$\begin{array}{l}\mathrm{C} 4 \text { fraction } \\
\text { retained }\end{array}$} & \multirow[t]{2}{*}{$\begin{array}{l}\mathrm{C} 3 \text { fraction } \\
\text { retained }\end{array}$} \\
\hline & 1999 & 2014 & & & & & & \\
\hline Control & $32.9 \pm 1.9$ & $28.9 \pm 0.7$ & $2.9 \pm 0.3$ & $0.31 \pm 0.03$ & 0 & $6.8 \pm 0.9$ & $0.38 \pm 0.08$ & NA \\
\hline Control $+\mathrm{N}$ & $36.0 \pm 1.8$ & $33.9 \pm 1.1$ & $6.4 \pm 0.2$ & $0.73 \pm 0.03$ & 0 & $8.9 \pm 1.1$ & $0.26 \pm 0.03$ & NA \\
\hline Straw & $42.7 \pm 1.5$ & $40.3 \pm 1.4$ & $3.9 \pm 0.2$ & $0.44 \pm 0.03$ & 1.77 & $6.2 \pm 0.6$ & $0.36 \pm 0.04$ & $0.04 \pm 0.08$ \\
\hline Straw + N & $45.8 \pm 0.6$ & $46.0 \pm 0.4$ & $7.5 \pm 0.4$ & $0.88 \pm 0.04$ & 1.77 & $5.6 \pm 1.7$ & $0.18 \pm 0.04$ & $0.1 \pm 0.05$ \\
\hline
\end{tabular}


continuous grain maize cropping for $\sim 30$ to 36 years; Balesdent et al. 1988) and partly to the relatively low net primary production of maize under the cold climate conditions of Central Sweden. The fact that all aboveground residues of maize were removed also contributed to the relatively low accumulation rate of $\mathrm{C} 4 \mathrm{C}$ observed in the present study.

The observed increases in ${ }^{13} \mathrm{C}$ abundance in the experimental treatments corresponded to $2.0-3.0 \mathrm{Mg} \mathrm{ha}^{-1}$ (Fig. 2). By subtracting these amounts from the observed change in SOC between 1999 and 2015, we were able to calculate the C3derived $\mathrm{C}$ stock changes in the four treatments. Since straw was the only $\mathrm{C} 3$ source during that period, differences between straw-amended and unamended $\mathrm{C} 3$ stock changes could be attributed to straw alone (Eq. 4). According to this calculation, $1.0 \mathrm{Mg} \mathrm{SOC} \mathrm{ha}{ }^{-1}$ was attributable to straw in the $\mathrm{N}$ treatment and $2.8 \mathrm{Mg} \mathrm{SOC} \mathrm{ha}{ }^{-1}$ in the $+\mathrm{N}$ treatments. The negative $\mathrm{C} 4-\mathrm{C}$ value in the $+\mathrm{N}$ treatments (Fig. 3) resulted from higher C4-SOC stocks in the $\mathrm{N}$ than in the Straw $+\mathrm{N}$ treatment. This reflects the fact that the fertilisation effect of straw was higher in the $-\mathrm{N}$ than in the $+\mathrm{N}$ treatments. As a result of straw addition, maize yield was on average 39 and $21 \%$ higher in the $-\mathrm{N}$ and $+\mathrm{N}$ treatments, respectively, over the 16 years. This positive effect can be attributable to mineralisation of additional plant nutrients and to improved soil structure (Kumar and Goh 1999). Furthermore, the four investigated treatments did already differ in SOC stocks in 1999. It is likely that SOC mineralisation was higher in those treatments with higher SOC stocks, which could also explain

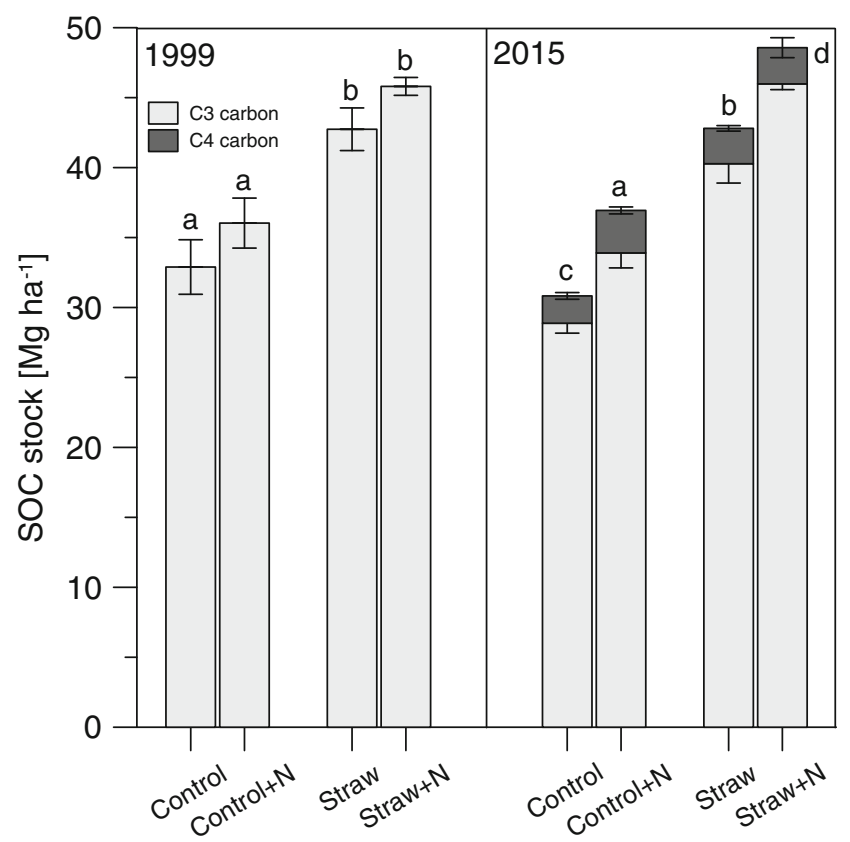

Fig. 2 Effect of treatments on maize-derived (C4) and $\mathrm{C} 3$ soil organic $\mathrm{C}$ (SOC) stocks. Treatments labelled with different letters are significantly different (Tukey's HSD, $\alpha=0.05$ ). Error bars indicate standard deviations

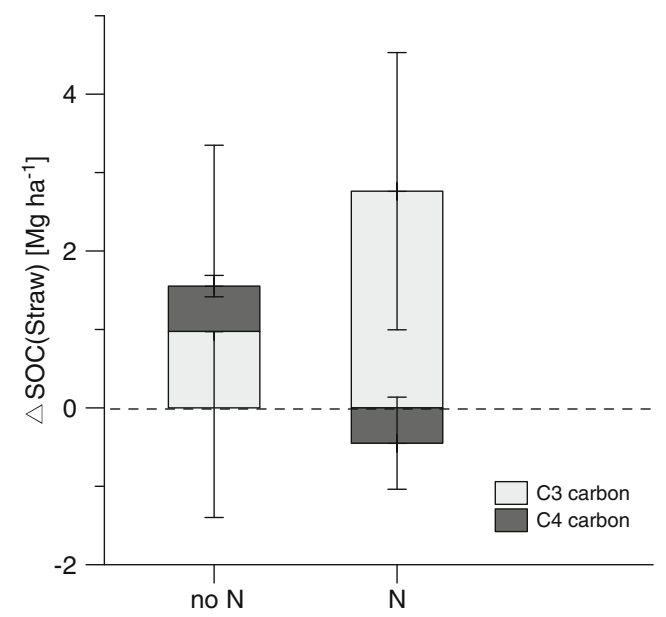

Fig. 3 Effect of straw $\mathrm{C}$ addition on the dynamics of $\mathrm{C} 3$ and $\mathrm{C} 4 \mathrm{C}$ stocks in the treatments without $(-\mathrm{N})$ and with $(+\mathrm{N})$ fertilisation (as calculated by Eqs. 3 and 4). Error bars indicate standard deviations

the higher retention of $\mathrm{C} 4$ roots in the Control treatments as compared to the straw-amended treatments (Table 2) and finally the calculated 'negative' effect of straw addition on $\mathrm{C} 4$ carbon.

\section{Retention of straw and root $\mathrm{C}$}

In agricultural ecosystems, management practises such as crop rotation or mineral and organic fertilisation can have effects on $\mathrm{C}$ sequestration (Smith et al. 2005; Jagadamma and Lal 2010 ). Soil C sequestration efficiency or retention rate of $\mathrm{C}$ inputs can be determined from the proportion of applied $\mathrm{C}$ that is retained as SOC. Our study demonstrated that $\mathrm{N}$ fertilisation resulted in lower retention of $\mathrm{C} 4-\mathrm{C}$ input than in the treatment without $\mathrm{N}$ (Fig. 3). The percentage of C4-C input retained through maize residues was 38, 26, 36 and $18 \%$ in the Control, Control $+\mathrm{N}$, Straw and Straw $+\mathrm{N}$ treatments, respectively, with the value in the $-\mathrm{N}$ treatments being significantly higher than in $+\mathrm{N}$ treatments. The high retention coefficient for maize roots in the Straw treatment and the low value in the Straw $+\mathrm{N}$ treatment are in agreement with Menichetti et al. (2013), who reported an average retention coefficient for maize roots of $0.30 \pm 0.09$ in the Ultuna field experiment. The higher retention coefficient of roots in the $-\mathrm{N}$ treatments (Control and Straw) than the $+\mathrm{N}$ treatments (Control $+\mathrm{N}$ and Straw $+\mathrm{N})($ Table 2) indicates that for roots, the effect of $\mathrm{N}$ fertilisation on microbial $\mathrm{C}$ use efficiency was masked by shifts in $\mathrm{C}$ allocation to aboveground and belowground plant organs. Since total root $\mathrm{C}$ inputs were not measured, but estimated using treatmentindependent allocation coefficients, the observed differences in $\mathrm{C}$ retention suggest that this allocation was affected by $\mathrm{N}$ fertilisation. This effect has been reported previously for cereals (Welbank et al. 1973), but also for perennial grasses 
(Sochorová et al. 2016) and can be explained by the fact that under $\mathrm{N}$ deficiency, plants need to invest more in roots to optimise nutrient acquisition. Furthermore, also a higher investment of the maize plants into symbiosis with mycorrhiza under nutrient deficiency could play a role, since those have been found to be important for SOC sequestration (Hobbie and Hobbie 2006). Thus, apart from the obvious influence of $\mathrm{N}$ fertilisation on net primary productivity (NNP), it also alters the ratio at which plants allocate their assimilates above- and belowground as well as potentially the rate at which $\mathrm{C}$ is incorporated into microbial biomass and ultimately into the SOC stock (Miltner et al. 2012). In the present study, both processes were observed, which corresponds to result $\mathrm{F}$ in Table 1 and points to the complexity of nutrient effects on SOC cycling. The fact that the likely effect of $\mathrm{N}$ fertilisation on root biomass opposed the $\mathrm{N}$ effect on straw retention may indicate that the absolute influence of altered plant $\mathrm{C}$ allocation overrode the influence of altered microbial $\mathrm{C}$ use efficiency. It should however be mentioned, that the investigated treatments did potentially also vary in soil moisture due to different SOC contents and plant water uptake, which might have affected SOC decomposition. This influence was however not quantified and both, differences in plant water uptake and differences in SOC across treatments, should have balances each other to some extent.

The estimated retention coefficient of $\mathrm{C} 3$ straw $(28 \mathrm{Mg}$ $\mathrm{C} \mathrm{ha}{ }^{-1}$ for 16 years) in the Straw $+\mathrm{N}$ treatment $(10 \%)$ was about three-fold higher than in the Straw-N treatment (4\%) (Fig. 3, Table 2). These values are slightly lower than those obtained using the ICBM model in the Ultuna frame trial, for which Poeplau et al. (2015) estimated 'humification coefficients' of 0.12 and 0.16 for the Straw and Straw $+\mathrm{N}$ treatment, respectively. We found 10-fold (Straw) and 1.6-fold (Straw $+\mathrm{N}$ ) higher retention of root-derived $\mathrm{C}$ than shoot-derived $\mathrm{C}$. This confirms findings from the mass balance approach used by Kätterer et al. (2011), who noted that the retention coefficients of roots were generally higher than those of aboveground plant residue amendments such as straw, sawdust or green manure in the Ultuna field experiment. The much higher retention of straw in the Straw $+\mathrm{N}$ treatment could point to higher substrate use efficiency of microbes, as reported by Kirkby et al. (2014). Higher substrate use efficiency (i.e. greater accumulation of microbial metabolites per unit of $\mathrm{C}$ uptake) is explained by the fact that microbial growth is co-limited by nutrients in a specific and relatively constant stoichiometric C:N:P:sulphur (S) ratio (Cleveland and Liptzin 2007; Kirkby et al. 2011; Tahir et al. 2016). In their study, Kirkby et al. (2014) found up to three-fold greater conversion of straw $\mathrm{C}$ into fine-fraction SOC upon nutrient addition, which is well in line with the results of our study (2.9-fold greater retention).

\section{Soil organic $\mathrm{C}$ fractions as influenced by management options}

The distribution of SOC in the fractions varied considerably between treatments. The POM fraction had SOC stocks ranging from 1.21 to $3.46 \mathrm{Mg} \mathrm{C} \mathrm{ha}^{-1}$ and accounted for 4.2 to $7.5 \%$ of total SOC, with significant differences between treatments (Table 3). The highest POM stocks were found in the straw-amended treatments, which can be explained by the higher input of labile plant residues. In a Danish soil, Magid et al. (1997) incubated wheat straw for 20 months and found up to $20 \%$ of the added straw still remaining as POM. The speed at which the straw residues are processed by microbes and partly transferred to more stable SOC pools depends strongly on climate conditions. In an Italian long-term experiment, Poeplau et al. (2016b) found no difference in POM stocks between 'residues removed' and 'residues incorporated' treatments. In contrast to the POM fraction, in the present study, the proportions of SOC attached to silt and clay (SCrSOC and rSOC) were higher in the treatments without straw addition (Control and N). These findings are in line with Zimmermann et al. (2007) and Poeplau and Don (2013), who reported that the largest fraction of SOC was the SCrSOC fraction, which accounted for 58-60\% in cropland, $51-59 \%$ in grassland and $41-58 \%$ in forests, followed by the rSOC, POM, SA and DOC fractions. Over both sampling dates and all treatments, we found $87.6 \%$ of the total SOC stock in the silt and clay fraction, which is in line with results reported by Flessa et al. (2008), who found $88 \%$ of the total SOC in this fraction in two German agricultural soils. Christensen and Sorensen (1985) also found $50-75 \%$ of SOC to be present in clay-sized separates, while silt accounted for another $20-40 \%$. This highlights the importance of organo-mineral interactions, as well as silt-sized microaggregates, for SOC stabilisation (Ladd et al. 1996; Christensen 1987; An et al. 2015; Moreno-Cornejo et al. 2015). Furthermore, Mueller et al. (2014) found that the sand-sized fraction was dominated by fresh organic matter rich in $\mathrm{O} / \mathrm{N}$-alkyl $\mathrm{C}$, while the silt-sized fraction was dominated by highly altered SOM rich in alkyl-C, suggesting a clear shift from carbohydrate- to alkyl chain-dominated SOM with decreasing bioavailability. This fits our observations, that the SA fraction was more enriched in fresh organic matter as compared to the fine SC fraction.

Interestingly, we observed a change in SOC distribution between the two sampling dates. In all four treatments, the more labile fractions POM, DOC and SA showed a relative decline between 1999 and 2015, while the more refractory fractions SC-rSOC and rSOC showed a relative increase (Table 3 ). Since the only factor that changed between the two sampling dates was the crop grown, it can be assumed that this shift to a more stable SOC stock was related to the introduction of maize. 


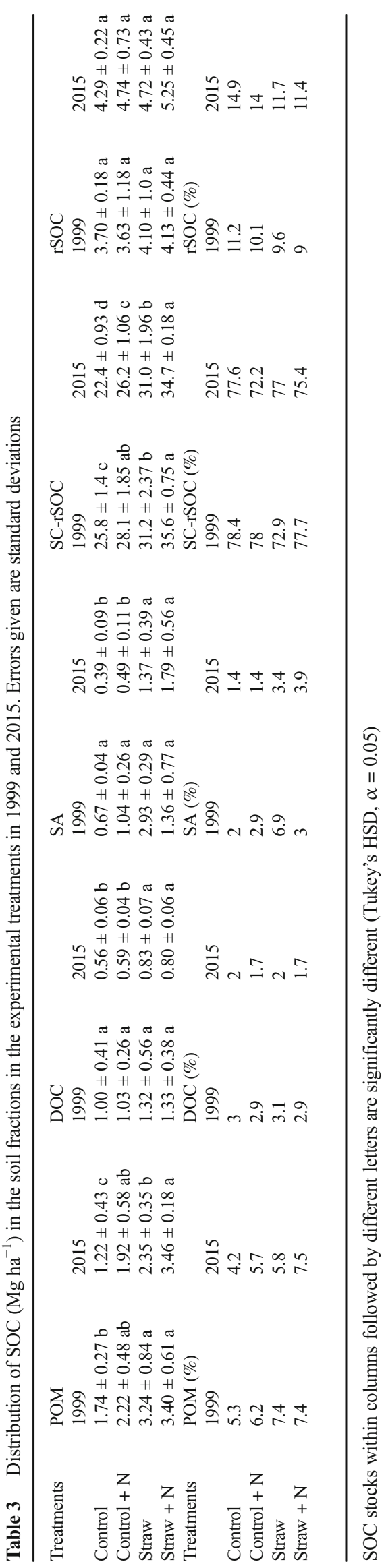

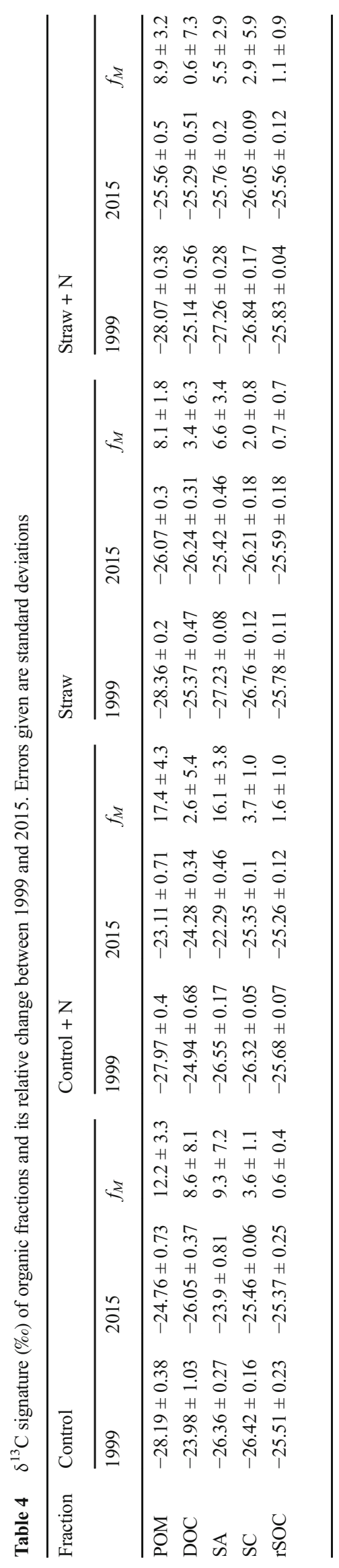




\section{C4-C enrichment in different fractions}

The change in $\delta^{13} \mathrm{C}$ of bulk soil and fractions across all treatments is shown in Table 4 . The proportion of maize-derived $\mathrm{C}$ was greatest in the POM fraction, with relative enrichment ranging from $8.1 \%$ (Straw) to $17.4 \%($ Control $+\mathrm{N})$. This is in line with several other studies and confirms that POM is the most active and dynamic SOC fraction. Kristiansen et al. (2005) reported that the POM fraction comprised $17-41 \%$ in different Danish soils after 11 years of maize cropping. Poeplau and Don (2014) found that after 16 years of Miscanthus plantation, $68 \%$ of the POM in the $0-10 \mathrm{~cm}$ soil layer was Miscanthus-derived. The enrichment of ${ }^{13} \mathrm{C}$ was less pronounced in the other fractions, in the order $\mathrm{SA}>\mathrm{SC}>\mathrm{rSOC}>\mathrm{DOC}$. Apart from the negative ${ }^{13} \mathrm{C}$ enrichment observed in the liquid DOC fraction in three out of four treatments, this ranking is in agreement with previous results (Poeplau and Don 2014) and supports the concept of the

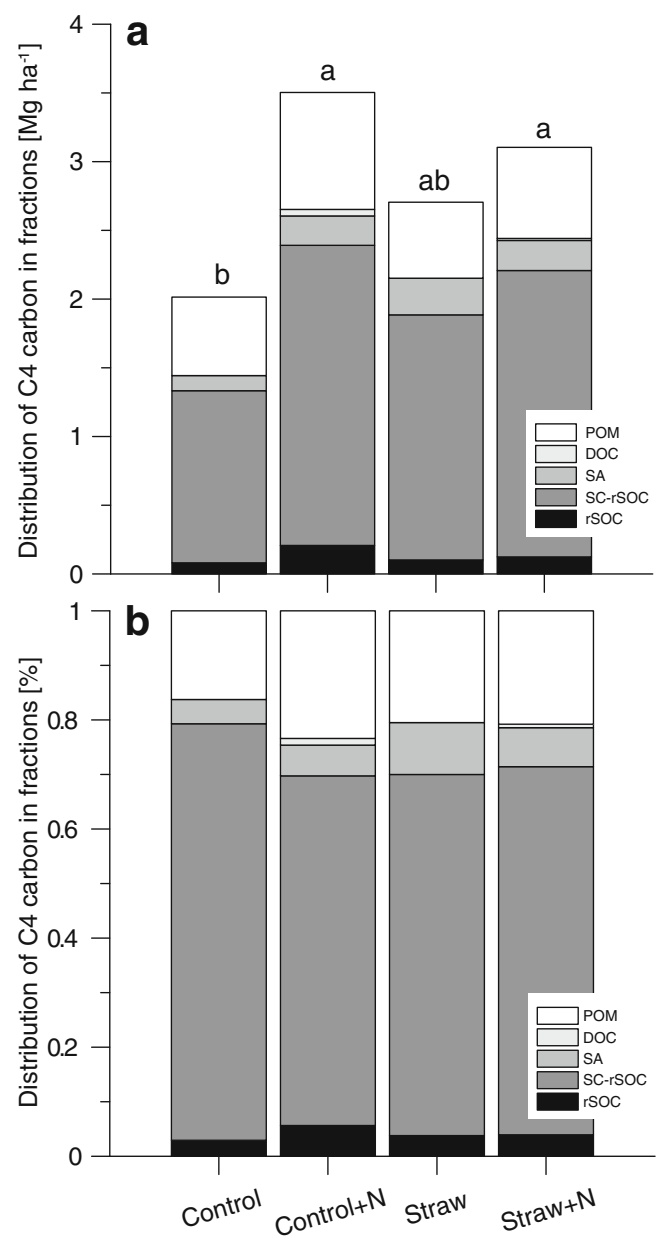

Fig. 4 Effect of treatments on distribution of C4-derived SOC into different fractions. a Absolute values and $\mathbf{b}$ percentage distribution among fractions. Treatments labelled with different letters are significantly different (Tukey's HSD, $\alpha=0.05$ ) regarding the total C4-derived SOC stocks fractionation method proposed by Zimmermann et al. (2007). However, the observed enrichment of C4 C within the rSOC fraction indicates that this pool is not passive, but its contribution to $\mathrm{C}$ cycling is detectable within a relatively short period of 16 years. This confirms the findings reported by several others (Dondini et al. 2009; Poeplau and Don 2014) and underlines that this fraction cannot directly be linked to the inert organic matter pool of the Rothamsted carbon model as suggested by Zimmermann et al. 2007. But the negative values for $\mathrm{C} 4$ enrichment in the DOC fraction can be explained by high measurement uncertainty due to very low SOC concentrations in the freeze-dried DOC samples.

Among treatments, significantly higher rates of $\delta^{13} \mathrm{C}$ enrichment were found in the POM fraction of the Control and Control $+\mathrm{N}$ treatment than of the Straw and Straw $+\mathrm{N}$ treatment (Table 3). This can be explained by the POM fraction being significantly larger in the straw-amended treatments, where the ${ }^{13} \mathrm{C}$ signal of the $\mathrm{C} 4 \mathrm{C}$ was diluted every second year by $\mathrm{C} 3$ straw inputs. However, in absolute terms, no difference was observed between control and straw-fertilised treatments in terms of C4-POM accumulation. The distribution of C4-C among SOC fractions, as influenced by management, is presented in Fig. 4. As can be seen from Fig. 4b, which depicts the relative distribution of $\mathrm{C} 4 \mathrm{C}$ in different SOC fractions, there was no clear treatment effect on the distribution of root-derived $\mathrm{C}$ in different $\mathrm{SOC}$ fractions.

\section{Conclusion and perspectives}

The unique combination of $\mathrm{C} 4$ root and $\mathrm{C} 3$ shoot residue inputs under field conditions allowed these to be studied separately regarding their incorporation into total SOM and its fractions. The results obtained provided additional evidence that root-derived $\mathrm{C}$ inputs are preferentially stabilised compared with shoot-derived inputs. We also observed an opposing response of roots and shoots (straw) to $\mathrm{N}$ fertilisation, which illustrates the diversity of nutrient effects on SOC cycling potentially present in the soil. We concluded that allocation coefficients used to estimate root $\mathrm{C}$ inputs should consider the nutrient status of the crop. To do so, more in situ experimental data regarding nutrient effects on $\mathrm{C}$ inputs are required. The SOC fractionation we conducted revealed that straw addition led to relative accumulation of labile fractions such as POM. Therefore, the positive effect on SOC stocks might not be long-lasting once straw addition is terminated. In contrast, the introduction of maize roots caused a shift in fraction distribution towards more stable fractions, such as SOC bound to silt and clay particles, most likely due to a higher contribution of roots to these $\mathrm{C}$ fractions. We concluded that rotations which include crops or intercrops with large amounts of root biomass are probably more beneficial than straw incorporation for long-term SOC storage. 
Open Access This article is distributed under the terms of the Creative Commons Attribution 4.0 International License (http:// creativecommons.org/licenses/by/4.0/), which permits unrestricted use, distribution, and reproduction in any medium, provided you give appropriate credit to the original author(s) and the source, provide a link to the Creative Commons license, and indicate if changes were made.

\section{References}

An TT et al (2015) Dynamics and distribution of ${ }^{13} \mathrm{C}$-labeled straw carbon by microorganisms as affected by soil fertility levels in the black soil region of Northeast China. Biol Fertility Soils 51:605-613. doi:10.1007/s00374-015-1006-3

Balesdent J, Mariotti A, Guillet B (1987) Natural ${ }^{13} \mathrm{C}$ abundance as a tracer for studies of soil organic-matter dynamics. Soil Biol Biochem 19:25-30. doi:10.1016/0038-0717(87)90120-9

Balesdent J, Wagner GH, Mariotti A (1988) Soil organic matter turnover in long-term field experiments as revealed by ${ }^{13} \mathrm{C}$ natural abundance. Soil Sci Soc Am J 52:118-124

Bol R, Poirier N, Balesdent J, Gleixner G (2009) Molecular turnover time of soil organic matter in particle-size fractions of an arable soil. Rapid Commun Mass Spectrom 23:2551-2558. doi:10.1002 rcm.4124

Bolinder MA, Andren O, Katterer T, de Jong R, VandenBygaart AJ, Angers DA, Parent LE, Gregorich EG (2007) Soil carbon dynamics in Canadian agricultural Ecoregions: quantifying climatic influence on soil biological activity. Agric Ecosyst Environ 122:461-470. doi:10.1016/j.agee.2007.03.001

Boutton TW (1996) Stable carbon isotope ratios of soil organic matter and their use as indicators of vegetation and climate change. In: Boutton TW, Yamasaki S (eds) Mass spectrometry of soils. Marcel Dekker, New York, pp. 47-82

Boutton TW, Archer SR, Midwood AJ, Zitzer SF, Bol R (1998) $\delta^{13} \mathrm{C}$ values of soil organic carbon and their use in documenting vegetation change in a subtropical savanna ecosystem. Geoderma 82:5-41. doi:10.1016/s0016-7061(97)00095-5

Börjesson G, Menichetti L, Thornton B, Campbell CD, Kätterer T (2016) Seasonal dynamics of the soil microbial community: assimilation of old and young carbon sources in a long-term field experiment as revealed by natural ${ }^{13} \mathrm{C}$ abundance. Eur J Soil Sci 67:79-89. doi:10.1111/ejss. 12309

Christensen BT (1987) Decomposability of organic matter in particle size fractions from field soils with straw incorporation. Soil Biol Biochem 19:429-435. doi:10.1016/0038-0717(87)90034-4

Christensen BT, Sorensen LH (1985) The distribution of native and labeled carbon between soil particle size fractions isolated from long-term incubation experiments. J Soil Sci 36:219 229

Christopher SF, Lal R (2007) Nitrogen management affects carbon sequestration in north American cropland soils. Crit Rev Plant Sci 26: 45-64. doi:10.1080/07352680601174830

Clapp CE, Allmaras RR, Layese MF, Linden DR, Dowdy RH (2000) Soil organic carbon and ${ }^{13} \mathrm{C}$ abundance as related to tillage, crop residue, and nitrogen fertilization under continuous corn management in Minnesota. Soil Tillage Res 55:127-142. doi:10.1016/S0167-1987 (00)00110-0

Cleveland CC, Liptzin D (2007) C: N: P stoichiometry in soil: is there a "Redfield ratio" for the microbial biomass? Biogeochemistry 85 : 235-252

Coleman K, Jenkinson D (1999) RothC-26.3. A model for the turnover of carbon in soils: model description and windows users guide. IACR, Rothamsted, Harpenden, UK
Dondini M, Hastings A, Saiz G, Jones MB, Smith P (2009) The potential of Miscanthus to sequester carbon in soils: comparing field measurements in Carlow, Ireland to model predictions. Glob Change Biol Bioenergy 1:413-425. doi:10.1111/j.1757-1707.2010.01033.x

Farquhar GD, Ehleringer JR, Hubick KT (1989) Carbon isotope discrimination and photosynthesis. Annu Rev Plant Physiol Plant Mol Biol 40:503-537. doi:10.1146/annurev.arplant.40.1.503

Flessa $\mathrm{H}$ et al (2008) Storage and stability of organic matter and fossil carbon in a Luvisol and Phaeozem with continuous maize cropping: a synthesis-review article. J Plant Nutr Soil Sci 171:36-51

Fontaine S, Barot S, Barre P, Bdioui N, Mary B, Rumpel C (2007) Stability of organic carbon in deep soil layers controlled by fresh carbon supply. Nature 450:277-U210. doi:10.1038/nature06275

Gregorich EG, Ellert BH, Monreal CM (1995) Turnover of soil organicmatter and storage of corn residue carbon estimated from natural ${ }^{13} \mathrm{C}$ abundance. Can J Soil Sci 75:161-167

Gregorich EG, Drury CF, Ellert BH, Liang BC (1997) Fertilization effects on physically protected light fraction organic matter. Soil Sci Soc Am J 61:482-484

Haile-Mariam S, Collins HP, Wright S, Paul EA (2008) Fractionation and long-term laboratory incubation to measure soil organic matter dynamics. Soil Sci Soc Am J 72:370-378. doi:10.2136 /sssaj2007.0126

Hobbie JE, Hobbie EA (2006) $15 \mathrm{~N}$ in symbiotic fungi and plants estimates nitrogen and carbon flux rates in arctic tundra. Ecology 87: $816-822$

Jagadamma J, Lal R (2010) Distribution of organic carbon in physical fractions of soils as affected by agricultural management. Biol Fertil Soils 46:543-554

Kätterer T, Bolinder MA, Andrén O, Kirchmann H, Menichetti L (2011) Roots contribute more to refractory soil organic matter than aboveground crop residues, as revealed by a long-term field experiment. Agric Ecosyst Environ 141:184-192. doi:10.1016/j. agee.2011.02.029

Kätterer T, Bolinder MA, Berglund K, Kirchmann H (2012) Strategies for carbon sequestration in agricultural soils in northern Europe. Acta Agr Scand A Ani Sci 62:181-198. doi:10.1080 /09064702.2013.779316

Kell DB (2012) Large-scale sequestration of atmospheric carbon via plant roots in natural and agricultural ecosystems: why and how? Philos Trans R Soc Lond Ser B Biol Sci 367:1589-1597. doi:10.1098 /rstb.2011.0244

Kirchmann H, Pichlmayer F, Gerzabek MH (1996) Sulfur balances and sulfur-34 abundance in a long-term fertilizer experiment. Soil Sci Soc Am J 60:174-178

Kirkby CA, Kirkegaard JA, Richardson AE, Wade LJ, Blanchard C, Batten G (2011) Stable soil organic matter: a comparison of C:N: P:S ratios in Australian and other world soils. Geoderma 163:197208. doi:10.1016/j.geoderma.2011.04.010

Kirkby CA, Richardson AE, Wade LJ, Batten GD, Blanchard C, Kirkegaard JA (2013) Carbon-nutrient stoichiometry to increase soil carbon sequestration. Soil Biol Biochem 60:77-86. doi:10.1016/j. soilbio.2013.01.011

Kirkby CA, Richardson AE, Wade LJ, Passioura JB, Batten GD, Blanchard C, Kirkegaard JA (2014) Nutrient availability limits carbon sequestration in arable soils. Soil Biol Biochem 68:402-409. doi:10.1016/j.soilbio.2013.09.032

Kristiansen SM, Hansen EM, Jensen LS, Christensen BT (2005) Natural ${ }^{13} \mathrm{C}$ abundance and carbon storage in Danish soils under continuous silage maize. Eur J Agron 22:107-117. doi:10.1016/j. eja.2004.01.002

Kumar K, Goh KM (1999) Crop residues and management practices: effects on soil quality, soil nitrogen dynamics, crop yield, and nitrogen recovery. In: Donald LS (Ed) Advances in Agronomy, vol Volume 68. Academic Press, London, pp 197-319. doi: 10.1016 /S0065-2113(08)60846-9 
Ladd JN, Foster RC, Nannipieri P, Oades JM (1996) Soil structure and biological activity. In: Stotzky, G., Bollag, J.M. Rao, M.A. et al. (Eds.), Soil Biol Biochem, Vol. 32 (pp. 1007-1014)

Lal R (2004) Soil carbon sequestration impacts on global climate change and food security. Science 304:1623-1627. doi:10.1126 /science.1097396

Liang BC, Gregorich EG, MacKenzie AF, Schnitzer M, Voroney RP, Monreal CM, Beyaert RP (1998) Retention and turnover of corn residue carbon in some eastern Canadian soils. Soil Sci Soc Am J 62:1361-1366

Magid J, Jensen LS, Mueller T, Nielsen NE (1997) Size-density fractionation for in situ measurements of rape straw decomposition - an alternative to the litterbag approach? Soil Biol Biochem 29:11251133. doi:10.1016/S0038-0717(96)00306-9

Mendez-Millan M, Dignac MF, Rumpel C, Rasse DP, Derenne S (2010) Molecular dynamics of shoot vs. root biomarkers in an agricultural soil estimated by natural abundance ${ }^{13} \mathrm{C}$ labelling. Soil Biol Biochem 42:169-177. doi:10.1016/j.soilbio.2009.10.010

Menichetti L, Ekblad A, Katterer T (2013) Organic amendments affect $\delta^{13} \mathrm{C}$ signature of soil respiration and soil organic $\mathrm{C}$ accumulation in a long-term field experiment in Sweden. Eur J Soil Sci 64:621-628. doi:10.1111/ejss.12077

Miltner A, Bombach P, Schmidt-Brücken B, Kästner M (2012) SOM genesis: microbial biomass as a significant source. Biogeochemistry 111:41-55. doi:10.1007/s10533-011-9658-z

Moreno-Cornejo J, Zornoza R, Doane TA, Faz A, Horwath WR (2015) Influence of cropping system management and crop residue addition on soil carbon turnover through the microbial biomass. Biol Fertility Soils 51:839-845. doi:10.1007/s00374-015-1030-3

Mueller CW, Gutsch M, Kothieringer K, Leifeld J, Rethemeyer J, Brueggemann N, Kögel-Knabner I (2014) Bioavailability and isotopic composition of $\mathrm{CO}_{2}$ released from incubated soil organic matter fractions. Soil Biol Biochem 69:168-178. doi:10.1016/j. soilbio.2013.11.006

Murphy CJ, Baggs EM, Morley N, Wall DP, Paterson E (2015) Rhizosphere priming can promote mobilisation of N-rich compounds from soil organic matter. Soil Biol Biochem 81:236-243

Peltre C, Christensen BT, Dragon S, Icard C, Kätterer T, Houot S (2012) RothC simulation of carbon accumulation in soil after repeated application of widely different organic amendments. Soil Biol Biochem 52:49-60. doi:10.1016/j.soilbio.2012.03.023

Poeplau C, Don A (2013) Sensitivity of soil organic carbon stocks and fractions to different land-use changes across Europe. Geoderma 192:189-201

Poeplau C, Don A (2014) Soil carbon changes under Miscanthus driven by $\mathrm{C}_{4}$ accumulation and $\mathrm{C}_{3}$ decompostion - toward a default sequestration function. Glob Change Biol Bioenergy 6:327-338. doi:10.1111/gcbb.12043

Poeplau C, Don A, Vesterdal L, Leifeld J, Van Wesemael B, Schumacher J, Gensior A (2011) Temporal dynamics of soil organic carbon after land-use change in the temperate zone - carbon response functions as a model approach. Glob Chang Biol 17:2415-2427. doi:10.1111 /j.1365-2486.2011.02408.x
Poeplau C, Kätterer T, Bolinder MA, Börjesson G, Berti A, Lugato E (2015) Low stabilization of aboveground crop residue carbon in sandy soils of Swedish long-term experiments. Geoderma 237: 246-255. doi:10.1016/j.geoderma.2014.09.010

Poeplau C, Bolinder MA, Kirchmann H, Kätterer T (2016a) Phosphorus fertilisation under nitrogen limitation can deplete soil carbon stocks: evidence from Swedish meta-replicated long-term field experiments. Biogeosciences 13:1119-1127. doi:10.5194/bg-13-1119-2016

Poeplau C, Reiter L, Berti A, Kätterer T (2016b) Qualitative and quantitative response of soil organic carbon to 40 years of crop residue incorporation under contrasting nitrogen fertilisation regimes. Soil Res. doi:10.1071/SR15377

Rasse DP, Rumpel C, Dignac MF (2005) Is soil carbon mostly root carbon? Mechanisms for a specific stabilisation. Plant Soil 269: 341-356. doi:10.1007/s11104-004-0907-y

R Development Core Team (2010) R: A language and environment for statistical computing. R Foundation for Statistical Computing, Vienna, Austria

Smith P, Andrén O, Karlsson T, Perälä P, Regina K, Rounsevell M, Van Wesemael B (2005) Carbon sequestration potential in European croplands has been overestimated. Glob Change Biol 11:21532163. doi:10.1111/j.1365-2486.2005.01052.xf

Sochorová L, Jansa J, Verbruggen E, Hejcman M, Schellberg J, Kiers ET, Johnson NC (2016) Long-term agricultural management maximizing hay production can significantly reduce belowground $\mathrm{C}$ storage. Agric Ecosyst Environ 220:104-114

Tahir MM, Recous S, Aita C, Schmatz R, Pilecco GE, Giacomini SJ (2016) In situ roots decompose faster than shoots left on the soil surface under subtropical no-till conditions. Biol Fertility Soils 52: 853-865. doi:10.1007/s00374-016-1125-5

von Lützow M, Kögel-Knabner I, Ekschmitt K, Flessa H, Guggenberger G, Matzner E, Marschner B (2007) SOM fractionation methods: relevance to functional pools and to stabilization mechanisms. Soil Biol Biochem 39:2183-2207. doi:10.1016/j.soilbio.2007.03.007

von Lützow M, Kögel-Knabner I, Ekschmitt K, Matzner E, Guggenberger G, Marschner B, Flessa H (2006) Stabilization of organic matter in temperate soils: mechanisms and their relevance under different soil conditions - a review. Eur J Soil Sci 57:426445. doi:10.1111/j.1365-2389.2006.00809.x

Wang JZ, Wang XJ, Xu MG, Feng G, Zhang WJ, Yang XY, Huang SM (2015) Contributions of wheat and maize residues to soil organic carbon under long-term rotation in North China. Sci Rep 5:11409. doi:10.1038/srep11409

Welbank PJ, Gibb MJ, Taylor PJ, Williams ED (1973) Root growth of cereal crops. Rothamsted Experimental Station Report. Part 2 - pp 26-66. http://www.era.rothamsted.ac.uk/eradoc/article/ResReport1973p2-2668 Accessed 25 July 2016

Zimmermann M, Leifeld J, Schmidt MWI, Smith P, Fuhrer J (2007) Measured soil organic matter fractions can be related to pools in the RothC model. Eur J Soil Sci 58:658-667. doi:10.1111/j.13652389.2006.00855.x 